\title{
Antecedents of Customer E-loyalty With the Effect of Trustworthiness in Malaysia Context
}

\author{
Poh-Ming Wong Winnie \\ University College of Technology Sarawak, Sarawak, Malaysia \\ May-Chiun Lo \\ University Malaysia Sarawak, Sarawak, Malaysia \\ Ramayah Thurasamy \\ University Sains Malaysia, Penang, Malaysia
}

\begin{abstract}
The rapid growth of online shopping has led to inspire customer e-loyalty among Malaysians, especially living in this digital environment. Commitment-trust theory is applied as the theoretical base to explain the factors influencing customer e-loyalty. The primary objective of this study is to investigate the direct impact of customer interface quality, service quality (SERVQUAL), website quality, technology acceptance factors, and technology trust on customer e-loyalty. This study also aims to examine the indirect effect of independence variables on customer e-loyalty through the effects of trustworthiness. SmartPLS 2.0 (M3) is applied as analytical tool to study the impact. A survey is conducted with 395 respondents who had online purchase experience. The findings indicated that customer interface quality, SERVQUAL, website quality, technology acceptance factors, and technology trust have positive impact on customer e-loyalty. Additionally, trustworthiness is used as mediator exclusive of SERVQUAL. Several implications of the findings, limitations of the study, and recommendations for future research are highlighted.
\end{abstract}

Keywords: customer interface quality, service quality (SERVQUAL), website quality, technology acceptance factors, technology trust, e-loyalty, trustworthiness

\section{Introduction}

The continuous growth of IT encouraged more Malaysians to do their shopping on the internet, which now pervades all aspects of daily life (Chopra \& Wallace, 2003). It is the best form of interaction between buyers and e-vendors (Khatibi, Thyagarajan, \& Seetharaman, 2003) and the most efficient medium of service delivery to e-consumers, e-government, and e-retailers (Mahmud, 2008). The internet, furthermore, is considered as the

Poh-Ming Wong Winnie, Ph.D., School of Business and Management, University College of Technology Sarawak, 96000 Sibu, Sarawak, Malaysia.

May-Chiun Lo, Ph.D., accosiate professor, Faculty of Economics and Business, University Malaysia Sarawak, 94300 Sarawak, Malaysia.

Ramayah Thurasamy, Master, professor, Technology Management Lab, Operations Management Section, School of Management, University Sains Malaysia, 11900 Penang, Malaysia.

Correspondence concerning this article should be addressed to Poh-Ming Wong Winnie, University College of Technology Sarawak, 868 Persiaran Brooke, 96000 Sibu Sarawak, Malaysia. Tel: +6084367300; Fax: +6084 367301. E-mail: winniewong@ucts.edu.my. 
source of communication and entertainment platform. It is also functioning as a new direct marketing tool to tailor products and services on websites and to extend this to e-business (Swaminathan, Lepkowska-White, \& Rao, 1999). Unfortunately, the percentage of Malaysians using the internet is relatively low (Zawawi, Yusuf, \& Khan, 2004). This could have been due to the issues of e-insecurity and privacy and also the ambiguity of regulations (Khatibi et al., 2003).

In Malaysia, e-shopping started in 2004, although it has been growing for almost eight years, Malaysian consumers were unfamiliar with and doubtful about this concept (Khatibi, Haque, \& Karim, 2006). However, some consumers tend to shop online due to some factors such as convenience, lower price, more product choice (Chua, Khatibi, \& Ismail, 2006), and cost saving (Kohli, Devaraj, \& Mohmood, 2004). The vast majority are likely to purchase books and flight tickets and to reserve hotel rooms (Lim, Yap, \& Lau, 2010). Hence, this study aims to gain a deeper understanding of customer e-loyalty amongst Malaysians. Specifically, it investigates the positive impact of customer interface quality, SERVQUAL, website quality, technology acceptance factors, and technology trust on customer e-loyalty. This study also investigates an indirect effect of the constructs on customer e-loyalty through trustworthiness.

\section{Literature Review}

\section{E-loyalty}

The term e-loyalty is applicable to consumers who are likely to buy from the same website, rather than switch to other websites (Flavián, Guinaliu, \& Gurrea, 2006). In this study, e-loyalty is defined as perceived loyalty of customers towards websites and their intention to visit the same website on their second purchase. There are various complex drivers of e-loyalty according to Choi, S. I. Kim, and S. H. Kim (2010), Collier and Bienstock (2006), Deb and Chavali (2009), and Ponirin, Scott, and Von Der Heidt (2009). Therefore, for the purpose of this study, authors adopt three dimensions to examine customer e-loyalty: word-of-mouth, complaining behavior, and future purchase intention.

In the virtual world, word-of-mouth does not involve direct interaction with e-retailers and it influences consumers' perception in the long term (Buttle, 1998). In this context, e-word-of-mouth is referred to the content of information that is to be spread out and share opinions and also their past experience to the consumers quickly via the internet (Hennig-Thurau, Gwinner, Walsh, \& Gremler, 2004). In the literature reviewing, word-of-mouth is an efficient platform than advertising, print ads, radio, and personal selling (Lin, Tzeng, Chin, \& Chang, 2010). In fact, it is four times more efficient than personal selling, twice more efficient than using the radio, and seven times more efficient than using newspapers and magazines (Schoefer, 1998). Therefore, as stated by Katz and Lazarsfeld (1955) that word-of-mouth was the resourceful tool to influence purchasing decisions (Gruen, Osmonbekov, \& Czaplewski, 2006).

Moreover, purchase intention is defined as a consumer's favorable intention to purchase products or services (Sam \& Tahir, 2010). Whitlark, Geurts, and Swenson (1993) described purchase intention as when individuals, having evaluated a product or service, followed with actual purchase behavior (Lin et al., 2010). Pavlou (2003) suggested that purchase intention occurs when consumers are willing to shop online and engage in e-transactions (Kwek, Lau, \& Tan, 2010). In this study, e-purchase intention evaluates an individual's behavior of purchase intention in the digital world (Salisbury, R. A. Pearson, A. W. Pearson, \& Miller, 2001).

Additionally, complaining behavior is a negative response of dissatisfaction (Chirico \& Presti, 2008), which leads to unsatisfied customers and negative word-of-mouth and discourages re-patronage (Blodgett, 
Wakefield, \& Barnes, 1995). Unsatisfied customers are likely to share their negative experiences with 11 persons compared to satisfied customers, who shared their experiences with about six persons (Hart, Heskett, \& Sasser, 1990). However, although these consumers are unsatisfied, they are still likely to purchase the goods or service, maintain the relationship, generate positive word-of-mouth, and create trust (Tax, Brown, \& Chandrashekaran, 1998). In line with this, Technical Assistance Report Programs also found that the consumers who are likely to complain had higher repurchase intentions than non-complain consumers (Richins, 1983).

\section{Antecedents of Customer E-loyalty}

Customer interface quality. Having a professional and good quality of website's interface is important in the virtual world. This is due to the fact that a blend of information will reach the potential customer quickly despite the high quality of website's interface. Besides, e-consumers and internet users are intended to purchase from the well-managed website's interface and it leads to successful business among e-retailers in this highly competitive e-environment. They are a range of dimensions of customer interface quality that significantly contributed to customer e-loyalty, for example, Swaminathan et al. (1999) indicated that cultivation, choice, community, convenience, customization, character, and interactivity are driven to e-loyalty (Mutum \& Ghazali, 2010). Srinivasan, Anderson, and Ponnavolu (2002a) proposed seven antecedents of loyalty namely, customization, interactivity, cultivation, character, and convenience (Broekhuizen, 2006). For the purpose of this study, authors adapt convenience, customization, interactivity, and character. Convenience refers to ease of navigation, easy to sort information, and takes a short time to involve in the process of e-purchasing (Ye \& Jia, 2010). According to the survey study of catalog age's consumer shopping behavior, $67 \%$ of the consumers concern the convenience factors on website shopping (Kau, Tang, \& Ghose, 2003). Customization is related to the relevant information that matched the consumer's needs (R. Dholakia, Zhao, N. Dholakia, \& Fortin, 2000). With customized website, e-consumers ease to create their own website to record their history of purchase, relevant products or services information, and their preference (J. H. Kim, M. Kim, \& Kandampully, 2009). Furthermore, interactivity is a two-way communication process or interaction between the e-consumers and website (Srinivasan et al., 2002a). An efficient interactivity helps more e-consumers to address the needed information easily (Alba et al., 1997). It is therefore to attract and retain e-consumers with the same e-store (Cyr, Head, \& Ivanov, 2009). In addition, due to the problem of indirect interaction between e-consumers and e-retailers, the attribute of character played a role as a "salesperson" in this manner. Character is defined as the surface looks of website or aesthetic (e.g., text and graphic). Having an aesthetical or emotional appealing on website captures more e-consumer to have one stop to look for it (Beaird, 2007).

Service quality. Service quality (SERVQUAL) is defined as an evaluation of service performance by service providers (Ye \& Jia, 2010). Zeithaml, Parasuraman, and Malhotra (2002) defined SERVQUAL as an imperative of website to assist e-purchasing and delivery products and services (Al-Momani \& Noor, 2009). The dimensions introduced by Parasuraman, Zeithaml, and Berry (1988) namely, responsiveness, reliability, empathy, assurance, and tangible are widely used scale. These five dimensions of SERVQUAL would be selected to measure customer e-loyalty in this study. This is due to that there is a limited study of research attached in the online outlook than offline SERVQUAL in the research study. Empathy is defined as an individualized attention (Gefen, Silver, \& Devine, 2001) and deals with personalization given to e-customers (C. N. Madu \& A. A. Madu, 2002). McKnight and Chervany (2002) stated that assurance is related to trusting beliefs and trusting intentions on certain websites (McKnight, Choudhury, \& Kacmar, 2002). Tangible refers to 
the image that displayed on the website. Griffith and Krampf (1998) found that responsiveness is an effective predictor in delivering service via online (Zeithaml et al., 2002). Reliability means the belief of service provider in providing the service accordant with their reliable and dependent manner (Gefen et al., 2001), timely, and accurate product presentation (Zeithaml et al., 2002).

Website quality. Website quality is a platform of information technology (IT) (Liu \& Arnett, 2000). Good quality of website is important to gain the customer's belief, trusts in certain e-store, and boost the sales. The visualization website provides better understanding of e-customer behavior, enhances customer loyalty, and gives an effective customer service to customers (Ganapathy, Ranganathan, \& Sankaranarayanan, 2004). In this study, authors adapt three dimensions of website quality namely, website design, website content, and website structure. Well-established website is attracting, ease-of-use, enhancing the users' skills, strengthening the long term relationship with buyers and sellers (Chen, Huang, Hsu, Tseng, \& Lee, 2010), and predicting the success of e-business (Tarafdar \& Zhang, 2008). Furthermore, website content is an important body of the website performance which focused by e-consumers (Nielsen, 1999). This information includes fast product search, value-added, and customized information (Liang \& Lai, 2002). Additionally, website structure is defined as overall information of online companies and convenience of displayed information on website (Wang \& Emurian, 2005). This website's structure will reflect the customer's view of website information, products, or services (Nielsen, 1999).

Technology acceptance factors. There are three important attributes of technology acceptance factors perceived usefulness, perceived ease-of-use, and perceived enjoyment. Perceived usefulness is noted as the use of technology that improves a consumer's performance (Davis, 1989). Usefulness itself is one of the benefits of using the internet. Despite perceived usefulness, perceived ease-of-use is defined as the degree of belief amongst individuals that is free of effort (Al-Momani \& Noor, 2009); easy to use, easy to read, and quick to download (Lederer, Maupin, Sena, \& Zhuang, 2000). In the literature, "user friendliness" (Purosothuman, 2008) of website is emphasized as well as its usability (Swaminathan et al., 1999). To this extent, ease of use affects e-purchasing intention (Klopping \& McKinney, 2004). Lastly, perceived enjoyment is defined as the degree of performance (Davis, 1982) and intrinsic motivators in technology acceptance (Davis, 1989). This refers to the pleasurable feelings of technology use (Rauyruen, Miller, \& Barrett, 2007).

Technology trust. Security is the important task of the internet (Suh \& Han, 2003) and it is defined as technical safety in the virtual world against the hackers (Cox \& Dale, 2001). E-security is referred to the secure of personal information and reduce the e-purchase risks (Yang, Jun, \& Peterson, 2004). In this sense, an individual consumer believes that internet is secure in transaction and transmitting the personal information data in the database of online company (Salisbury et al., 2001). Apart from that, privacy is acknowledged as an individual control and limits their information to the e-retailers on website (Ribbink, van Riel, Liljander, \& Streukens, 2004). Privacy is also defined as the personal data protection from hackers without other e-consumer's knowledge (Deb \& Chavali, 2009) such as the personal detail information (e.g., mobile number), total amount of every trip of online purchasing, and financial information (e.g., credit card's number). These characteristics are expected to influence the confidence level of e-consumers and affect the amount of e-consumers to engage in purchasing behavior (Shim, Van Slyke, Jiang, \& Johnson, 2010). Statistically, 69\% of the e-users are unwilling to inform their personal information to the e-retailers, if they do not explain how their personal data to be use in e-store (Hoffman, Novak, \& Paralta, 1999). 


\section{Trustworthiness}

Trust and trustworthiness are two different contexts (Toma, 2010). Trust is defined as an act of a trustor (Corritore, Kracher, \& Wiedenbeck, 2003), however, trustworthiness is acknowledged as the characteristics of trustees that are worthy to trust (Rusman, Van Bruggen, \& Koper, 2007). According to Serva, Benamati, and Fuller (2005), trustworthiness leads to trust and both of these are not similar but are linked with each other (Akter, D’Ambra, \& Ray, 2011). In this study, trustworthiness is played a role as mediator. Trustworthiness embodies the worthy attributes perceived by individual called trustier (Pittayachawan, 2007). In the model of Mayer, Davis, and Schoorman (1995), trustworthiness includes three dimensions: ability, benevolence, and integrity. In this study, authors adopt three specific beliefs on honesty, benevolence, and competence. In the literature reviewing, benevolence is defined as perceived courtesy of trustee towards trustors (Rusman et al., 2007). Competence is the knowledge, talents, and expertise that wish to complete the purchasing (Hosmer, 1995). It entails the knowledge and skills of trustee to desire trustors (Chopra \& Wallace, 2003). Additionally, consumers believe that trustee will be honest, sincere, and comply with its commitments (Chiu, Chang, Cheng, \& Fang, 2009) by providing good and reliable flow of service in delivering the promises as promised (Chen \& Dhillon, 2003).

\section{Technology Acceptance Model (TAM)}

TAM is an influential model (Baraghani, 2007) that is established by Davis (1989). It is developed based on theory of reasoned action (TRA) by Fishbein and Ajzen (1975), who adapted belief-attitude-intention-behavioral relationship to IT acceptance. TAM and TRA are relevant in exploring website use intention in this research. In TRA, beliefs influence an individual's attitude and lead to behavioral intentions. Researchers in the past have applied TAM in technology acceptance (Catalán \& Laque, 2010), e-commerce (Hernández, Jiménez, \& Martín, 2009), e-transaction (Katos, 2009), and e-purchasing intentions (Tang \& Chi, 2010).

\section{Commitment-trust Theory (CTT)}

Despite applying TAM, this study also adopts CTT to explain how trustworthiness links with the customer e-loyalty. CTT, generally, is developed by Morgan and Hunt (1994), which assigns trust and commitment as mediator. CTT has been applied in e-tourism (Kim, Chung, \& Lee, 2010), e-banking (Lii, 2009), and e-commerce (Chen et al., 2010), and user behavior of computer (Corritore et al., 2003). In CTT, trust and commitment are closely linked and build up strong relationship among sellers and buyers (Mukherjee \& Nath, 2007). Trust convinces people who have higher confidence (Moorman, Zaltman, \& Deshpande, 1992). Commitment involves vulnerability, however, it plays a prime role of exchange partner relationship which forms and maintains the long lasting relationship with other people (Morgan \& Hunt, 1994). Veloutsou, Saren, and Tzokas (2002) argued that CTT led to customer retention (Abosag, Tynan, \& Lewis, 2006). Trust is also important to reduce risks, lead to e-purchase intention, and maintain relationship with customers (Wen, 2009).

\section{Development of Hypotheses}

Previous studies have found that customer interface factors contributed to e-loyalty (Mehta, 2005). As stated in literatures, the element of interactivity ( $\mathrm{Ng} \&$ Matanda, 2008), customization (Kassim \& Ismail, 2009; Tarafdar \& Zhang, 2008), and convenience (Chang \& Chen, 2008) positively impact customer e-loyalty. Accordingly, SERVQUAL also influenced e-store loyalty in e-retailing (Ponirin et al., 2009). Despite 
SERVQUAL, website content, website structure, website performance, and attractiveness are found to perform e-loyalty (Palmer, 2002). Wolfinbarger and Gilly (2003) indicated that well-designed website has positive impact on customer loyalty (Koo, 2006). Numerous research studies showed that usefulness, ease-of-use, and enjoyment influence attitude and e-purchasing intention (Monsuwé, Dellaert, \& de Ruyter, 2004; Van Der Heijden \& Verhagen, 2004). A survey study found that usefulness and ease of use positively impact consumer's attitude of e-retailing in Hong Kong (Liao \& Shi, 2009) and intentions to use e-service (Roca, García, \& De La Vega, 2009). Additionally, e-security affects e-loyalty (Tarafdar \& Zhang, 2008). Thereby, this paper hypothesized that:

$\mathrm{H1}$ :Customer interface quality is positively related to customer e-loyalty;

H2: Good SERVQUAL is positively related to customer e-loyalty;

H3: Good website quality is positively related to customer e-loyalty;

H4: Technology acceptance factors are positively related to customer e-loyalty;

H5: Technology trust is positively related to customer e-loyalty.

Several researchers have explained the influence of trust on customer e-loyalty (Ribbink et al., 2004). When the customers trust e-retailers, they will disclose their personal information (Kim, 2003), the e-retailers are easier to deal with in the future and money transactions easier to track. Moreover, trust is an efficient marketing tool, which can attract more customers to engage in future buying behavior (Gefen, 2000) and influence their e-purchasing intentions (Jarvenpaa, Tractinsky, \& Vitale, 2000). Thereby, this paper posited that:

H6: Trustworthiness is positively related to customer e-loyalty.

Mediating Role of Trustworthiness. Trust mediates the relationship between interactivity and e-loyalty (Cyr et al., 2009). The finding of Ribbink et al. (2004) and Kassim and Ismail (2009) identified that customization insignificantly affects trust in online buying. Deriving on this evidence, this paper implies that trustworthiness mediates the relationship between customer interface quality and customer e-loyalty. Besides, most of the consumers are unwilling to participate in e-purchasing due to the higher risks (e.g., financial risk). In this respects, e-service provider should improve their service in terms of empathy to increase consumer trust towards e-service, such as air-ticketing (Sam \& Tahir, 2010). The positive preference of website quality is the best predictor of e-trust and leads to customer e-loyalty (Deb \& Chavali, 2009). Karvonen (2000) found that the beauty of website assists trust building (Ganguly, Dash, \& Cyr, 2009). In this regards, authors expect that there is an indirect effect of developed constructs on customer e-loyalty through trustworthiness. Additionally, several studies (Flavián \& Guinaliu, 2006; Mukherjee \& Nath, 2007) showed that security influenced a person's trust in the Internet. The study of Kim et al. (2010) found that perceived security is linked to consumer trust in purchasing e-tourism products in South Korea. Apart from security, a sense of trust on security and privacy provided, it convinces the e-shoppers to use the website. The proposed hypotheses are stated as below:

H7: Trustworthiness mediates the relationship between customer interface quality and customer e-loyalty;

H8: Trustworthiness mediates the relationship between SERVQUAL and customer e-loyalty;

H9: Trustworthiness mediates the relationship between technology acceptance factors and customer e-loyalty;

H10: Trustworthiness mediates the relationship between website quality and customer e-loyalty;

H11: Trustworthiness mediates the relationship between technology trust and customer e-loyalty. 


\section{Methodology}

The survey site of this study is in Malaysia, specifically in Kuala Lumpur, PutraJaya, and CyberJaya. According to Malaysian Ministry of Energy, communication and multimedia have indicated that the concentration of internet users in Malaysia was very high (56\%) in central peninsula Malaysia, compared to Northern Malaysia (14\%), Southern Malaysia (11\%), Eastern Malaysia (5\%), Sabah (5\%), and Sarawak (5\%) (Nordin, 2002). Moreover, PutraJaya is a planned city and equipped with various modern facilities. As such, it is rational to assume that majority of the population is made up of technology savvy group, living in a technology-based society, and active internet users. Additionally, Cyberjaya (the Silicon Valley of Malaysia) is developed as IT-themed city with superior information communication technology, multimedia industries, research and development centers, and higher learning institutions (Multimedia University) (Retrieved from http://en.wikipedia.org/wiki/Cyberjaya). It is therefore to assume that majority of residents are well-educated, with high computer literacy and keen to use multimedia technology.

A self-administrated survey was used to obtain the primary data through a set of questionnaire. The questionnaire was divided into two parts. Part A described the predictors that affected customer e-loyalty. Part $\mathrm{B}$ focused on the respondent demographics. Each dimension contained multi-items measured by a seven-point Likert-scale. A total of 500 set of questionnaire were distributed and 405 sets were returned. Out of 405 returned questionnaire, 395 were usable. A non-probability purposive sampling method was conducted to select representative respondents, because these selected respondents were able to provide the needed information (Sekaran, 1992). Confidentiality was guaranteed in all cases.

\section{Findings}

The data is analyzed using SmartPLS 2.0 (M3). PLS is a latent variable modeling technique which incorporates the multiple dependent constructs and recognizes measurement error (Karim, 2009). It is more useful, because PLS has the ability to identify path relationships of statistical significance (Goodhue, Lewis, \& Thompson, 2006). Other powerful features of PLS path modeling are to examine the model fit in a straightforward manner, test the proposed hypotheses (Luo, Li, Zhang, \& Shim, 2010), and provide a more accurate estimation of the mediating effects by looking into the free measurement errors (Chin, Marcolin, \& Newsted, 2003).

Briefly, $53.9 \%$ of the respondents were female and males were $46.1 \%$. In this study, 230 respondents were still singles and 164 were married. Academically, a majority of the respondents had undergraduate degree holders $(n=307,77.7 \%)$ followed by master's degree $(n=41,10.4 \%)$ and lastly, diploma holders $(n=30$, $7.6 \%)$. Moreover, the respondents held a minimum secondary school level of qualification $(n=10,2.5 \%)$. With this educational attainment, it was rationale to indicate that they were cultured and knowledgeable. In this study, the category of 26 to 30 years old $(n=113,28.6 \%)$ was ranked the highest followed by $21.5 \%(n=85)$, in the range of 18 to 25 years old. As such, the younger consumers were well educated and having generous income to participate in e-commerce (Dillon \& Reif, 2004). Furthermore, it was about $21.3 \%(n=84)$ of 31 to 35 years old and 66 respondents (16.7\%) from the 36 to 40 years old group, and lastly 27 respondents $(6.8 \%)$ in the age group ranging from 41 to 45 years old. Regarding ethnic compositions, the sample consisted of more Chinese (48.4\%) than Malays (30.1\%), followed by Indians (8.9\%) and others (12.7\%). Next, the respondents recorded having a monthly income ranging from RM3,001 to RM5,000. Besides, 29.9\% were within the range from 
RM1,001 to RM3,000, followed by $17.5 \%$ who earned RM5001 to RM7000. Additionally, $43 \%$ of respondents were categorized as others and they were university or college students, waitresses, part-time workers, cleaners, and others. The second largest group was professionals which recorded $33.7 \%$ respondents followed by executives $(10.6 \%)$.

\section{Assessment of the Measurement Model}

Firstly, the statistical analysis was conducted to identify the causal relationships between the observed variables (items) and the underlying constructs. Hence, confirmatory factor analysis (CFA), including convergent validity and discriminant validity, was performed to measure the validity of the constructs of the study. As shown in Table 1, the item loadings in each construct exceeded the acceptable value of 0.5 , as suggested by Hair, Black, Babin, Anderson, and Tatham (2010). All average variance extracted (AVE) value exceeded the acceptable level, 0.5 (Halawi \& McCarthy, 2008) (see Table 2). All composite reliability (CR) fulfilled the recommended value (0.7) as suggested by Gefen, Straub, and Boudreau (2000) (see Table 2). Meanwhile, Cronbach $\alpha$ values for each constructs exceeded the ideal value of 0.7 as recommended by Sekaran (1992) (see Table 2). Therefore, the model constructs of this study achieved good convergent validity with the evidence of all items loaded higher on the proposed factors than other factors (own loading are higher than cross loadings) (Chin, 2010) (see Table 1). To assess discriminant validity, the square root of AVEs conducted to test the inter-correlation amongst the tested variables (Chin, 2010) (see Table 3 and Table 4). Overall, the results showed that the square root of AVE (in bold) exceeded the correlations with other variables. In summary, it is to confirm that the measurement model of this study is acceptable.

Table 1

Loading and Cross Loading

\begin{tabular}{llllllll}
\hline Constructs & CIQ & SERVQUAL & WEBQUAL & TAF & TEC_TRUST & E-LOY & T_WORHINESS \\
\hline CON & 0.752 & 0.543 & 0.574 & 0.543 & 0.429 & 0.554 & 0.543 \\
CUS & 0.860 & 0.742 & 0.890 & 0.734 & 0.679 & 0.725 & 0.729 \\
INT & 0.722 & 0.549 & 0.518 & 0.535 & 0.520 & 0.592 & 0.583 \\
CHA & 0.772 & 0.536 & 0.582 & 0.599 & 0.599 & 0.593 & 0.574 \\
EMP & 0.693 & 0.880 & 0.724 & 0.801 & 0.651 & 0.713 & 0.755 \\
ASS & 0.561 & 0.783 & 0.591 & 0.581 & 0.660 & 0.600 & 0.655 \\
TANG & 0.734 & 0.848 & 0.781 & 0.811 & 0.30 & 0.727 & 0.732 \\
RESP & 0.686 & 0.868 & 0.717 & 0.778 & 0.656 & 0.702 & 0.734 \\
REL & 0.682 & 0.856 & 0.704 & 0.703 & 0.679 & 0.669 & 0.750 \\
WDES & 0.895 & 0.742 & 0.890 & 0.734 & 0.679 & 0.725 & 0.729 \\
WCON & 0.784 & 0.792 & 0.942 & 0.801 & 0.699 & 0.731 & 0.763 \\
WSTR & 0.724 & 0.741 & 0.942 & 0.774 & 0.699 & 0.671 & 0.763 \\
PU & 0.743 & 0.798 & 0.762 & 0.906 & 0.701 & 0.730 & 0.779 \\
PEOU & 0.752 & 0.821 & 0.791 & 0.923 & 0.652 & 0.704 & 0.767 \\
ENJ & 0.670 & 0.756 & 0.750 & 0.899 & 0.563 & 0.674 & 0.679 \\
SEC & 0.639 & 0.738 & 0.698 & 0.683 & 0.933 & 0.663 & 0.766 \\
PRI & 0.636 & 0.698 & 0.653 & 0.629 & 0.929 & 0.655 & 0.733 \\
WOM & 0.693 & 0.731 & 0.668 & 0.722 & 0.673 & 0.862 & 0.688 \\
CB & 0.560 & 0.546 & 0.495 & 0.463 & 0.466 & 0.705 & 0.505 \\
FPI & 0.739 & 0.677 & 0.715 & 0.674 & 0.572 & 0.863 & 0.628 \\
HON & 0.673 & 0.770 & 0.730 & 0.753 & 0.681 & 0.647 & 0.862 \\
BEN & 0.700 & 0.756 & 0.694 & 0.688 & 0.744 & 0.682 & 0.903 \\
COMP & 0.718 & 0.767 & 0.717 & 0.748 & 0.729 & 0.684 & 0.910 \\
\hline
\end{tabular}


Table 2

Result of Measurement Model

\begin{tabular}{|c|c|c|c|c|c|}
\hline Model Construct & Measurement Item & Cronbach's $\alpha$ & Loading & $\mathrm{CR}^{\mathrm{a}}$ & $\mathrm{AVE}^{\mathrm{b}}$ \\
\hline \multirow{3}{*}{ E-loyalty } & WOM & 0.741 & 0.862 & \multirow{3}{*}{0.853} & \multirow{3}{*}{0.661} \\
\hline & FPI & & 0.863 & & \\
\hline & $\mathrm{CB}$ & & 0.705 & & \\
\hline \multirow{4}{*}{ CIQ } & $\mathrm{CON}$ & 0.745 & 0.752 & \multirow{2}{*}{0.840} & \multirow{2}{*}{0.569} \\
\hline & CUS & & 0.860 & & \\
\hline & INT & & 0.722 & & \\
\hline & CHA & & 0.772 & & \\
\hline \multirow{5}{*}{ SERVQUAL } & EMP & 0.902 & 0.880 & \multirow{5}{*}{0.927} & \multirow{5}{*}{0.719} \\
\hline & ASS & & 0.783 & & \\
\hline & TANG & & 0.848 & & \\
\hline & RESP & & 0.868 & & \\
\hline & REL & & 0.856 & & \\
\hline \multirow{3}{*}{ WEBQUAL } & WDES & 0.899 & 0.890 & \multirow{3}{*}{0.937} & \multirow{3}{*}{0.832} \\
\hline & WCON & & 0.942 & & \\
\hline & WSTR & & 0.942 & & \\
\hline \multirow{3}{*}{ TAF } & PU & 0.896 & 0.906 & \multirow{3}{*}{0.935} & \multirow{3}{*}{0.827} \\
\hline & PEOU & & 0.923 & & \\
\hline & ENJ & & 0.899 & & \\
\hline \multirow{2}{*}{ TEC_TRUST } & SEC & 0.846 & 0.933 & \multirow{2}{*}{0.928} & \multirow{2}{*}{0.866} \\
\hline & PRI & & 0.929 & & \\
\hline \multirow{3}{*}{ Trustworthiness } & $\mathrm{HON}$ & 0.871 & 0.862 & \multirow{3}{*}{0.921} & \multirow{3}{*}{0.796} \\
\hline & BEN & & 0.903 & & \\
\hline & COMP & & 0.910 & & \\
\hline
\end{tabular}

Notes. ${ }^{\text {a }}$ Composite reliability $(\mathrm{CR})=$ square of the summation of the factor loadings / (square of the summation of the factor loadings + square of the summation of the error variances) ${ }^{b}$ Average variance extracted (AVE) $=$ summation of the square of the factor loadings / (summation of the square of the factor loadings + summation of the error variances).

Table 3

Summary Results of the Model Constructs

\begin{tabular}{lllr}
\hline Model Construct & Measurement Item & Standardized estimate & t-value \\
\hline \multirow{3}{*}{ E-loyalty } & WOM & 0.862 & 33.040 \\
& FPI & 0.863 & 28.964 \\
\hline CIQ & CB & 0.705 & 9.052 \\
\hline \multirow{6}{*}{ CON } & 0.752 & 13.080 \\
\hline & CUS & 0.860 & 33.878 \\
& INT & 0.722 & 11.034 \\
& CHA & 0.772 & 9.496 \\
\hline & EMP & 0.880 & 33.940 \\
& ASS & 0.783 & 15.992 \\
WEBQUAL & TANG & 0.848 & 26.873 \\
& RESP & 0.868 & 33.694 \\
& REL & 0.856 & 29.530 \\
\hline
\end{tabular}


Table 3 continued

\begin{tabular}{llll}
\hline Model Construct & Measurement Item & Standardized estimate & t-value \\
\hline \multirow{2}{*}{ TAF } & PU & 0.906 & 51.821 \\
& PEOU & 0.923 & 53.701 \\
& ENJ & 0.899 & 36.089 \\
\hline \multirow{2}{*}{ TEC_TRUST } & SEC & 0.933 & 71.310 \\
& PRI & 0.929 & 56.910 \\
\hline \multirow{2}{*}{ Trustworthiness } & HON & 0.862 & 23.630 \\
& BEN & 0.903 & 43.542 \\
& COMP & 0.910 & 43.307 \\
\hline
\end{tabular}

Note. Final items numbers (initial numbers).

Table 4

Discriminant Validity of Constructs

\begin{tabular}{lllllll}
\hline Constructs & CIQ & E-LOY & SERVQUAL & TAF & TEC_TRUST & T_WORHINESS WEBQUAL \\
\hline CIQ & 0.754 & & & & & \\
E-LOY & 0.521 & 0.813 & & & & \\
SERVQUA & 0.594 & 0.606 & 0.848 & & & \\
TAF & 0.505 & 0.673 & 0.571 & 0.909 & & \\
TEC_T & 0.685 & 0.507 & 0.671 & 0.405 & 0.931 & 0.893 \\
T_WORTH & 0.581 & 0552 & 0.458 & 0.617 & 0.605 & 0.599 \\
WEBQUA & 0.588 & 0.478 & 0.432 & 0.544 & 0.526 & 0.912 \\
\hline
\end{tabular}

Note. Diagonals represent the square root of the average variance extracted while the other entries represent the correlations.

\section{Assessment of the Structural Model}

Once all the constructs in the measurement model were validated, structural model was then to be tested. The bootstrapping technique was conducted to generate $t$-value for each of the hypothesized relationship and the potential impact of covariates. The researcher conducted the bootstrapping approach with 500 samples, with 0 cases per sample to test the path coefficient $(\beta)$ and proposed hypotheses. Table 5 and Figure 1 presented the results of the hypotheses testing. The findings revealed that customer interface quality $(\beta$ $=0.457 ; t=3.974)$, SERVQUAL $(\beta=0.312, t=2.433)$, website quality $(\beta=0.169 ; t=3.333)$, technology acceptance factors $(\beta=0.329 ; t=2.575)$, technology trust $(\beta=0.139, t=3.410)$, and trustworthiness $(\beta=$ $0.035 ; t=2.265$ ) were found to be related to customer e-loyalty, with the evidence that these six formulated hypotheses exceeded the recommended value, $1.96(<0.05)$, hence, H1, H2, H3, H4, H5, and H6 were supported.

Generally, a global fit measure (GOF) was conducted for path modeling, it is defined as the geometric mean of average communality and average $R^{2}$ (especially endogenous variables) (Chin, 2010) (see the formula). In this study, GOF value was $0.61\left(R^{2}=0.747\right.$, average $\mathrm{AVE}=0.661$ for e-loyalty $)$ and $0.72\left(R^{2}=0.808\right.$, average $\mathrm{AVE}=0.796$ for trustworthiness). Both of GOF value exceeded the largest cut-off value $(0.36)$ and it was indicated that the proposed model of this study had better explaining power than that based on the recommended value of $\mathrm{GOF}_{\text {small }}=0.1, \mathrm{GOF}_{\text {medium }}=0.25$, and $\mathrm{GOF}_{\text {large }}=0.36$ (Akter et al., 2011).

$$
\mathrm{GOF}=\sqrt{\mathrm{AVE} \times R^{2}} \text {. }
$$


Table 5

Path Coefficient and Hypothesis Testing

\begin{tabular}{lllll}
\hline H & Relationship & Coefficient & $\boldsymbol{t}$-value & Decision \\
\hline H1 & CIQ $\rightarrow$ e-loyalty & 0.457 & 3.974 & YES \\
H2 & SEVQUAL $\rightarrow$ e-loyaly & 0.312 & 2.433 & YES \\
H3 & Website quality $\rightarrow$ e-loyalty & 0.169 & 3.333 & YES \\
H4 & TAF $\rightarrow$ e-loyalty & 0.329 & 2.575 & YES \\
H5 & Tech_trust $\rightarrow$ e-loyalty & 0.139 & 3.410 & YES \\
H6 & Trustworthness $\rightarrow$ e-loyalty & 0.035 & 2.265 & YES \\
H7 & CIQ trustworthness $\rightarrow$ e-loyalty & 0.141 & 1.200 & YES \\
H8 & SEVQUAL trustworthiness $\rightarrow$ e-loyaly & 0.328 & 3.167 & NO \\
H9 & Website quality trustworthiness $\rightarrow$ e-loyalty & 0.036 & 4.344 & YES \\
H10 & TAF trustworthness $\rightarrow$ e-loyalty & 0.169 & 4.519 & YES \\
H11 & Tech_trust trustworthiness $\rightarrow$ e-loyalty & 0.016 & 3.591 & YES
\end{tabular}

Note. . $t$-value $>1.96\left(p<0.05^{*}\right) ;$-value $>2.58\left(p<0.01^{* *}\right)$.

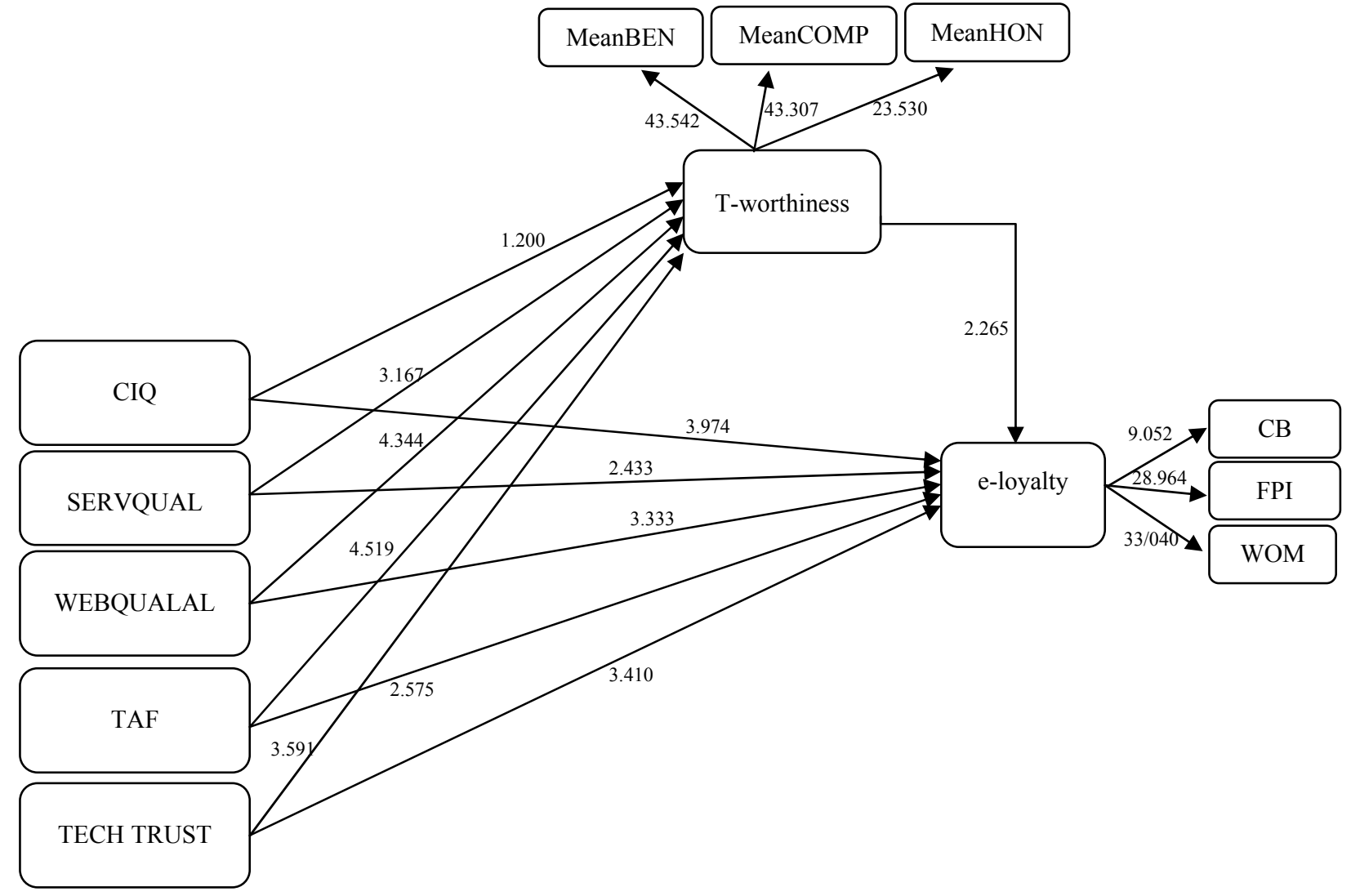

Figure 1. Research model with PLS coefficients.

\section{The Mediating Effect}

According to McKinnon, Warsi, and Dwyer (1995), the mediating effects only exist when (a) independent variables have a significant impact on mediator, (b) independence variables have a significant impact on dependent variables in the absence of mediator, (c) mediator has a significant impact on dependence variables, and (d) the effect of independent variables and dependence variables become smaller with the existence of mediator (Ramayah, Samat, \& Lo, 2011). The indirect effect of hypotheses has been presented in Table 5. 
SERVQUAL, website quality, technology acceptance factors, and technology trust were positively related to trustworthiness with $\beta=0.328, p<0.01 ; \beta=0.036, p<0.01 ; \beta=0.169, p<0.01$; and $\beta=0.016, p<0.01$ respectively, as well as trustworthiness on customer e-loyalty $(\beta=0.035, p<0.01)$. However, on the basis of testing the mediating effect, the findings revealed that customer interface quality was negatively related to trustworthiness $(\beta=0.141, p<0.01)$. Moreover, in terms of direct effect of independent variables and customer e-loyalty, all the proposed independent variables were related to customer e-loyalty. As such, it was rational to conclude that the indirect effect of SERVQUAL, website quality, technology acceptance factors, and technology trust were positively related to customer e-loyalty through the mediating effect of trustworthiness. In this sense, trustworthiness has played a key role as mediator in this study and, H8, H9, H10, and H11 was supported. H7 was rejected due to the fact that customer interface quality was not fulfilling the basic of mediating effect.

\section{Discussion}

The findings showed that there is a positive impact of customer interface quality, SERVQUAL, website quality, technology acceptance factors, and technology trust on customer e-loyalty. This study also found that there is an indirect effect of SERVQUAL, website quality, technology acceptance factors, and technology trust on customer e-loyalty through the mediating effect of trustworthiness. These generalized findings enticed e-consumers and internet users to participate in e-purchasing.

As expected, the findings of current study were in line with the study of Chang and Chen (2008) that customer interface factors contributed to customer e-loyalty. Srinivasan, Anderson, and Ponnavolu (2002b) also reported that interactivity influenced customer e-loyalty (Balabanis, Reynolds, \& Simintiras, 2006). Despite customer interface quality, Oliveira (2007) also found that e-SERVQUAL directly linked to customer e-loyalty (Lin \& Sun, 2009). This is due to the fact that acquiring new customers is costly exercise and the existing customer purchase more (Long \& McMellon, 2004). Generally, e-users generated favorable or unfavorable feeling towards the website from the first sight of accessing. As such, website quality is important in the e-consumer's point of view. Smith (2001) revealed that easy to navigate, dependable distribution systems, efficient website, and the value of products or services influenced customer e-loyalty (Olson \& Boyer, 2005). Due to the good website quality, Stanford, Tauber, Fogg, and Marable (2002) found that e-customers are more likely to access a given website accordance with good accessibility and attractive image of website (Corritore et al., 2003). The findings showed that perceived usefulness impacts customer loyalty of e-shopping (Shih, 2004). This finding is confirmed by Ha and Stoel (2009) that perceived usefulness, trust, and enjoyment are in turn to drive customer intention to shop online. Lastly, internet privacy and security relatively affected e-trust (Kim, 2003). Several studies (Belanger, Hiller, \& Smith, 2002; Kim \& Shim, 2002) have found that security is predictor of consumer intention to shop via online. This was due to the fact that many e-consumers are unwilling to provide personal information over the internet (Salisbury et al., 2001).

Another intriguing finding that emerged from this study was trustworthiness successfully mediated customer interface quality, website quality, technology acceptance, and technology trust factors on customer e-loyalty. When e-consumers or e-shoppers have had no direct interaction with the e-retailers, trustworthiness (trust beliefs) plays an important role. In other words, trust (trustworthiness) acts as a confidence tool to move potential customers towards website purchases, and thus spread favorable word-of-mouth to the others and their friends (Santos \& Von Der Heyde Fernandes, 2008). As stated in the literature reviewing, a sense of trust can 
be earned by repeatedly meeting customers' perceived value (Yao, Zhou, \&Meng, 2007) and providing accurate information (Abdul-Rahman \& Hailes, 2000). Trust also maintains the relationships and forms the commitment (Morgan \& Hunt, 1994). Therefore, there is an interrelationship between trust (trustworthiness), behavioral intention, and attitude towards e-purchasing from e-store. However, contrary to expectations, the research found that trustworthiness did not mediate SERVQUAL and customer e-loyalty. This finding may be the result of a failure in service provision by the e-retailer, during which they did not provide good individualized attention.

Apart from that, TAM has been adapted to help website designers and e-retailers better understand the impact of web technology on Malaysian internet users and potential or existing e-buyers. This study also utilized CTT which is built on the basis that trust and commitment were complements, to test the influence of trustworthiness through predictors, and has proven to be the useful theoretical base to explain technology acceptance in Malaysia context. It drove to explain, assure e-consumer behavior, and be able to interpret the effect of trustworthiness through numerous predictors on customer e-loyalty. A well-built trust and commitment aided to build up the strong relationship and strengthen the relationship between e-retailers and e-consumers in digital world. With this powerful relationship, trustworthiness played an indirect influence on customer e-loyalty in this study.

\section{Limitation and Direction of Future Research}

This study suffers from some limitations. Firstly, it lacked diversity in terms of the sample used. The survey concentrated on the urban area only without choosing rural areas. In other words, the respondents from urban area had different perceptions on technology use, such as online purchasing, from those who were not selected. As perceptions towards technology use change over the time, the findings of the present study were limited to the internet buyers only and also these specific locations. Secondly, the sample size of this study (395 samples) achieved and fulfiled Roscoe's rule (Sekaran, 1992). However, the researcher should maximize the samples to generate higher generalization of the findings in future. Thirdly, the quality of data used in this study may be doubted because of the way the questionnaire was answered by respondents. Fourthly, the product or service types should be under consideration. In this study, respondents were free to think of any product or service website before filling the questionnaire. In this regard, a future researcher has to classify clearly what products or services websites to use in order to avoid selecting inaccurate variables.

\section{Implication}

None of the studies have examined the developed constructs in this study and its direct impact on customer e-loyalty, in this sense, this study's insights will improve the understanding of the relationship between these constructs within Malaysia. This was expected to add to the body of knowledge on e-consumer behavior. The role of trustworthiness and its importance drove to customer e-loyalty among Malaysians. The effect of trustworthiness between the constructs and customer e-loyalty will also add more knowledge to the literature of e-commerce and online consumer behavior from an academic perspective. Presently, there is limited literature that focuses on the adoption, acceptance, and intention to use websites amongst Malaysians. Due to this, it was important for e-marketers to understand attitudes and behaviors' in order to encourage more Malaysians to involve in electronic-based activities. As reflected in the findings from the current study, marketing academics and professionals attempted to discover the most significant antecedents of customer e-loyalty which was important to e-business applications in Malaysia. These antecedents might assist the 
e-marketer and e-designers to develop and reengineer the strategic tools to promote Malaysians to use the Internet for shopping regarding to the re-patronage behavior in online shopping. The current research intends to generalize awareness of the usefulness of the internet. Consequently, the adoption intention of websites will be improved and, furthermore, perceptions towards computer use will be positive. In addition, the findings also revealed to e-retailers the importance of designing professional and well-structured websites with good content, in order to attract and retain existing and new e-consumers. As a result of rapid technological growth, the internet was the most effective marketing tool to deal with customers. Indeed, the volume of e-business will increase because of the ability to conduct business more quickly and across the country.

\section{Conclusions}

The analytical results indicated that customer interface quality, SERVQUAL, website quality, technology acceptance factors, and technology trust positively and direct related to customer e-loyalty. The findings also showed that there is an indirect effect of trustworthiness on customer e-loyalty. The generalized added to the body of literature in developing the antecedents of customer e-loyalty in Malaysia. This work also contributed to a better understanding of the determinants of e-purchasing behavior and intention amongst Malaysian e-consumers that led to prompt Internet marketing in the country. Generally speaking, it is of help for e-retailers and website designers to understand what Malaysian online buyers want, as well as how to encourage them to become involved in e-shopping. At the same time, Malaysian e-consumers perceive positively the internet as the fastest and most efficient communication channel. Apart from this, it increases the market share in this competitive marketplace and also helps e-marketers to develop a consistent web-based shopping strategy to boost the e-economy.

\section{References}

Abdul-Rahman, A., \& Hailes, S. (2000). Supporting trust in virtual communities. Proceedings from the 33rd Hawaii International Conference on System Sciences.

Abosag, I., Tynan, C., \& Lewis, C. (2006). The development of trust and relationship commitment within relationship life-cycle in Saudi Arabia. Proceedings from the European Marketing Academy Conference, Athens, Greece.

Akter, S., D’Ambra, J., \& Ray, P. (2011). Trustworthiness in health information services: An assessment of hierarchical model with mediating and moderating effects using partial least squares (PLS). Journal of the American Society for Information Science and Technology, 62(1), 100-116.

Alba, J., Lynch, J., Weitz, B., Janiszewski, C., Lutz, R., Sawyer, A., \& Wood, S. (1997). Interactive home shopping: Consumer, retailer, and manufacturer incentives to participate in electronic marketplace. Journal of Marketing, 61, 38-53.

Al-Momani, K., \& Noor, N. A. (2009). E-service quality, ease of use, and enjoyment as antecedents of e-CRM performance: An empirical investigation in Jordan mobile phone services. The Asian Journal of Management, 2(2), 11-25.

Balabanis, G., Reynolds, N., \& Simintiras, A. (2006). Bases of e-store loyalty: Perceived switching barriers and satisfaction. Journal of Business Research, 59, 214-224.

Baraghani, S. N. (2007). Factors influencing the adoption of internet banking (Master's thesis, Department of Business Administration and Social Sciences, Luleå University of Technology).

Beaird, J. (2007). The principles of beautiful web design. Melbourne: Site Point Pty. Ltd.

Belanger, F., Hiller, J. S., \& Smith, W. J. (2002). Trustworthiness in electronic commerce: The role of privacy, security, and site attributes. Journal of Strategic Information Systems, 11, 245-270.

Blodgett, J. G., Wakefield, K. L., \& Barnes, J. H. (1995). The effects of consumer service on consumer complaining behavior. Journal of Service Marketing, 9(4), 31-42.

Broekhuizen, T. (2006). Understanding channel purchase intentions: Measuring online and offline shopping value perceptions. (Doctoral Dissertation, University of Groningen, Labyrinth Publications). 
Buttle, F. A. (1998). Word of mouth: Understanding and managing referral marketing. Journal of Strategic Marketing, 6, 241-254.

Catalán, L., \& Laque, D. (2010). M-commerce adoption: TAM vs technology provider perspective through cognitive maps. Retrieved from file://C:/Users/Academic/Downloads/Dialnet-McommerceAdoption-2720205.pdf

Chang, H. H., \& Chen, S. W. (2008). The impact of customer interface quality, satisfaction, and switching costs on e-loyalty: Internet experience as a moderator. Computers in Human Behavior, 24(63), 2927-2944.

Chen, S. C., \& Dhillon, G. S. (2003). Interpreting dimensions of consumer trust in e-commerce. Information Technology and Management, 4, 303-318.

Chen, Y. Y., Huang, H. L., Hsu, Y. C., Tseng, H. C., \& Lee, Y. C. (2010). Confirmation of expectation and satisfaction with the internet shopping: The role of internet self-efficiency. Computer and Information Science, 3(3), 14-22.

Chin, W. W. (2010). How to write up and report PLS analyses. In V. Esposito, W. W. Chin, J. Henseler, \& H. Wang (Eds), Handbook of partial least squares: Concept, methods and applications (pp. 655-690). New York: Springer.

Chin, W. W., Marcolin, B. L., \& Newsted, P. R. (2003). A partial least squares latent variable modeling approach for measuring interaction effects: Result from a Monte Carlo simulation study and voice mail emotion/adoption study. Proceedings from the Seventeenth International Conference on Informaion Systems.

Chirico, P., \& Presti, A. L. (2008). A customer loyalty model for services based on a continuing relationship with the provider. Proceedings from Method, Models, and Information Technologies for Decision Support Systems, University Del Salento, Lecce.

Chiu, C. M., Chang, C. C., Cheng, H. L., \& Fang, Y. H. (2009). Determinants of customer repurchase intention in online shopping. Online Information Review, 33(4), 761-784.

Choi, D. H., Kim, S. I., \& Kim, S. H. (2000). Antecedents and behavioral consequences of customer satisfaction on internet retail store. International Center for Electronic Commerce. Retrieved from http://koasas.kaist.ac.kr/bitstream /10203/4785/1/2000-079.pdf

Chopra, K., \& Wallace, W. A. (2003). Trust in electronic environment. Proceeding from the 36th Annual Hawaii International Conference on System Sciences, Big Island, HI.

Chua, A. P. H., Khatibi, A., \& Ismail, H. (2006). E-commerce: A study on online shopping in Malaysia. Journal of Social Science, 13(3), 231-242.

Collier, J. E., \& Bienstock, C. C. (2006). Measuring service quality in e-tailing. Journal of Service Research, 8(3), 260-275.

Corritore, C. L., Kracher, B., \& Wiedenbeck, S. (2003). Online trust: Concepts, evolving themes, a model. International Journal Human-Computer Studies, 58, 737-758.

Cox, J., \& Dale, B. G. (2001). Service quality and e-commerce: An exploratory analysis. Managing Service Quality, 11(2), 121-131.

Cyr, D., Head, M., \& Ivanov, A. (2009). Perceived interactivity leading to e-loyalty: Development of a model for cognitive-affective user responses. International Journal Human-Computer Studies, 67, 850-869.

Davis, C. G. (1982). Linkages between socioeconomic characteristics, food expenditure patterns, and nutritional status of low income households: A critical review. American Agriculture Economic Association, 64(5), 1017-1025.

Davis, F. D. (1989). Perceived usefulness, perceived ease of use, and acceptance of information technology. MIS Quarterly, 13(3), 319-340.

Deb, M., \& Chavali, K. (2009). A study on the significant e-trust and e-loyalty in online banking. AIMS International Journal of Management, 3(2), 241-257.

Dholakia, R., Zhao, M., Dholakia, N., \& Fortin, D. (2000). Interactivity and revisits to websites: A theoretical framework. Retrieved from file://C:/Users/Academic/Downloads/interactivity-libre.pdf

Dillon, T. W., \& Reif, H. L. (2004). Factors influencing consumers' e-commerce commodity purchases. Information Technology, Learning and Performance Journal, 22(2), 1-12.

Fishbein, M., \& Ajzen, I. (1975). Belief, attitude, intention, and behavior: An introduction to theory and research. Reading: Addison-Wesley.

Flavián, C., \& Guinaliu, M. (2006). Consumer trust, perceived security, and privacy policy: Three basic elements of loyalty to a web site. Industrial Management \& Data, 106(5), 601-620.

Flavián, C., Guinaliu, M., \& Gurrea, R. (2006). The influence of the perceived usability on website loyalty: An empirical analysis. Retrieved

from http://www.escp-eap.eu/conferences/marketing/2005_cp/Materiali/Paper/Fr/FLAVIAN_GUINAL\%CDU_GURREA.pdf 
Ganapathy, S., Ranganathan, C., \& Sankaranarayanan, B. (2004). Visualization strategies and tools for enhancing customer relationship management. Communication of the ACM, 47(11), 93-99.

Ganguly, B., Dash, S. B., \& Cyr, D. (2009). Website characteristics, trust, and purchase intention in online stores: An empirical study in the Indian context. Journal of Information Science and Technology, 6(2), 22-44.

Gefen, D. (2000). E-commerce: The role of familiarity and trust. Omega, 28(6), 725-737.

Gefen, D., Silver, M., \& Devine, P. (2001). Service quality dimensions of business to consumer e-commerce. Retrieved from http://www.pages.drexel.edu

Gefen, D., Straub, D. W., \& Boudreau, M. C. (2000). Structural equation modeling and regression: Guidelines for research practice. Communication of the Association for Information Systems, 4(7), 1-79.

Goodhue, D., Lewis, W., \& Thompson, R. (2006). PLS, small sample size, and statistical power in MIS research. Proceedings from the 39th Hawaii International Conference on System Sciences.

Griffin. J. (2002). Customer Loyalty: How to Earn It How to Keep It. San Francisco: Jossey-Bass.

Griffith, D. A., \& Krampf, R. A. (1998). An examination of the web based strategies of the top 100 U.S. retailers. Journal of Marketing Theory and Practice, 6(3), 12-23.

Gruen, T. W., Osmonbekov, T., \& Czaplewski, A. J. (2006). E-WOM: The impact of customer-to-customer online know-how exchange on customer value and loyalty. Journal of Business Research, 59, 449-459.

Ha, H. Y. (2005). An integrative model of consumer satisfaction in the context of e-services. International Journal of Consumer Studies, 30(2), 137-149.

Ha, S., \& Stoel, L. (2009). Consumer e-shopping acceptance antecedents in a technology acceptance model. Journal of Business Research, 62, 565-571.

Hair, J. F., Black, W. C., Babin, B. J., Anderson, R. E., \& Tatham, R. L. (2010). Multivariate data analysis (6th ed.). Upper Saddle River: Prentice Hall.

Halawi, L., \& McCarthy, R. (2008). Measuring students perceptions of blackboard using the technology acceptance model: A PLS approach. Issues in Information Systems, 9(2), 95-102.

Hart, C. W. L., Heskett, J. L., \& Sasser, Jr., W. E. (1990). The profitable art of service recovery. Harvard Business Research, $68(4), 148-156$.

Hennig-Thurau, T., Gwinner, K. P., Walsh, G., \& Gremler, D. D. (2004). Electronic word-of-mouth via consumer-opinion platforms: What motivates consumers to articulate themselves on the internet? Journal of Interactive Marketing, 18(1), 38-52.

Hernández, B., Jiménez, J., \& Martín, M. J. (2010). Customer behavior in electronic commerce: The moderating effect of e-purchasing experience. Journal of Business Research, 63, 964-971.

Hoffman, D. L., Novak, T. P., \& Paralta, M. (1999). Building consumer trust online. Communications of the ACM, 42(4), 80-85.

Hosmer, L. T. (1995). Trust: The connecting link between organizational theory and philosophical ethics. Academy of Management Review, 20(2), 379-403.

Jarvenpaa, S. L., Tractinsky, N., \& Vitale, M. (2000). Consumer trust in an internet store. Information Technology and Management, 1(1), 45-71.

Karim, J. (2009). Emotional labor and psychological distress: Testing the mediatory role of work-family conflict. European Journal of Social Sciences, 11(4), 584-598.

Karvonen, K. (2000). The beauty of simplicity. Proceedings from the Conference on Universal Usability.

Kassim, N., \& Ismail, S. (2009). Investigating the complex drivers of loyalty in e-commerce settings. Measuring Business Excellence, 13(1), 56-71.

Katerattanakul, P. (2002). Framework of effective website design for business-to-consumer internet commerce. INFOR, 40(1), 57-69.

Katos, V. (2009). An integrated model for online transactions: Methodological issue and challenges. Methodological Innovations Online, 4(3), 27-40.

Katz, E., \& Lazarsfeld, P. F. (1955). Personal influence. Glencoe: Free Press.

Kau, A. K., Tang, Y., \& Ghose, S. (2003). Typology of online shoppers. Journal of Marketing, 20(2), 139-156.

Khatibi, A., Haque, A., \& Karim, K. (2006). E-commerce: A study on internet shopping in Malaysia. Journal of Applied Sciences, 6(3), 696-705.

Khatibi, A., Thyagarajan, V., \& Seetharaman, A. (2003). E-commerce in Malaysia: Perceived benefits and barriers. VIKALPA, $28(3), 77-82$. 
Kim, J. (2003). An integrative model of e-loyalty development process: The role of e-satisfaction, e-trust, e-tail quality, and situational factors (Master thesis, Yonsei University, Seoul, Korea).

Kim, J. H., Kim, M., \& Kandampully, J. (2009). Buying environment characteristics in the context of e-service. European Journal of Marketing, 43(9/19), 1188-1204.

Kim, M. J., Chung, N., \& Lee, C. K. (2010). The effect of perceived trust on electronic commerce: Shopping online for tourism products and services in South Korea. Tourism Management, 30, 1-10.

Kim, Y. M., \& Shim, K. Y. (2002). The influence of internet shopping mall characteristics and user traits on purchase intent. Irish Marketing Review, 15(2), 25-34.

Klopping, I. M., \& McKinney, E. (2004). Extending the technology acceptance model and the task-technology model to consumer e-commerce. Information Technology, Learning, and Performance Journal, 22(1), 1-2.

Kohli, R., Devaraj, S., \& Mohmood, M. A. (2004). Understanding determinants of online consumer satisfaction: A decision process perspective. Journal of Management Information, 21(1), 115-135.

Koo, D. M. (2006). The fundamental reasons of e-consumers' loyalty to an online store. Electronic Commerce Research and Applications, 5, 117-130.

Kwek, C. L., Lau, T. C., \& Tan, H. P. (2010). The effects of shopping orientations, online trust and prior online purchase experience toward customers' online purchase intention. International Business Research, 3(3), 63-76.

Lederer, A. L., Maupin, D. J., Sena, M. P., \& Zhuang, Y. (2000). The technology acceptance model and the world wide web. Decision Support Systems, 29, 269-282.

Liang, T. P., \& Lai, H. J. (2002). Effect of store design on consumer purchases: An empirical study of online bookstores. Information and Management, 39, 431-444.

Liao, Z., \& Shi, X. (2009). Consumer perceptions of internet-based e-retailing: An empirical research in Hong Kong. Journal of Service Marketing, 23(1), 24-30.

Lii, Y. S. (2009). A model of customer e-loyalty in the online banking. Economics Bulletin, 29(2), 891-902.

Lim, Y. M., Yap, C. S., \& Lau, T. C. (2010). Online search and buying behavior: Malaysian experience. Canadian Social Science, 6(4), 154-166.

Lin, C. S., Tzeng, G. H., Chin, Y. C., \& Chang, C. C. (2010). The effect of recommendation sources and consumer involvement on trust and purchase intention in online and offline environments. Retrieved from http://scholar.googleusercontent.com

Lin, G. T. R., \& Sun, C. C. (2009). Factors influencing satisfaction and loyalty in online shopping: An integrated model. Online Information Review, 33(3), 458-475.

Liu, C., \& Arnett, K. P. (2000). Exploring the factors associated with website success in the context of electronic commerce. Information and Management, 38, 23-33.

Long, M., \& McMellon, C. (2004). Exploring the determinants of retail service quality on the internet. Journal of Service Marketing, 18(1), 78-90.

Luo, X., Li, H. L., Zhang, J., \& Shim, J. P. (2010). Examining multi-dimensional trust snd multi-faceted risk in initial acceptance of emerging technologies: An empirical study of mobile banking services. Decision Support Systems, 49, 222-234.

Madu, C. N., \& Madu, A. A. (2002). Dimensions of e-quality. International Journal of Quality and Reliability Management, 19(3), 246-258.

Mahmud, M. N. (2008). Modeling the dynamics of internet adoption. Computer and Information Science, 1(1), 95-103.

Mayer, R. C., Davis, J. H., \& Schoorman, F. D. (1995). An integrative model of organizational trust. The Academy of Management Review, 20(3), 709-734.

McKinnon, D. P., Warsi, G., \& Dwyer, J. H. (1995). A simulation study of mediated effect measures. Multivariate Behavioral Research, 30(1), 1-62.

McKnight, D. H., Choudhury, V., \& Kacmar, C. (2002). The impact of initial consumer trust on intentions to transact with a web site: A trust building model. Journal of Strategic Information Systems, 11, 297-323.

Mehta, V. (2005). Customer loyalty in the virtual world: An examination based on evaluation of web offering in the Indian context. Proceedings from the IADIS International Conference e-Commerce.

Monsuwé, T. P., Dellaert, B. G. C., \& de Ruyter, K. (2004). What drivers consumers to shop online? A literature review. International Journal of Service Industry Management, 15(1), 102-121.

Moorman, C., Zaltman, G., \& Deshpande, R. (1992). Relationships between providers and users of market research: The dynamics of trust within and between organizations. Journal of Marketing Research, 24, 314-328. 
Morgan, R. M., \& Hunt, S. D. (1994). The commitment-trust theory of relationship marketing. Journal of Marketing, 58(3), 20-38.

Mukherjee, A., \& Nath, P. (2007). Role of electronic trust in online retailing. European Journal of Marketing, 41(9/10), 1173-1202.

Mutum, D., \& Ghazali, E. (2010). Online shoppers vs non-shoppers: A lifestyle study of Malaysian internet users. Retrieved from http://www2.warwick.ac.uk/alumni/services/eportfolios/bsrfbr/online_shoppers_vs_non-shoppers.pdf

Ng, J., \& Matanda, M. J. (2008). Determinants of e-loyalty and customer patronage in blog-retailing: A case study of retailers using blog retailing format in Singapore. Proceedings from the Australia and New Zealand Marketing Academy Conference 2008-Marketing: Shifting the Focus from Mainstream to Offbeat, 1-3 December 2008, Australia and New Zealand Marketing Academy (ANZMAC), Sydney NSW Australia.

Nielsen, J. (1999). Designing web usability. Indianapolis: New Riders Publishing.

Nordin, S. (2002). Revenue implications of e-commerce: Government and private sector experiences Malaysia. Proceedings from the WTO Regional Seminar on Electronic Commerce, Geneva, Switzerland.

Oliveira, R. C. (2007). Evidences from link between quality and loyalty in e-service: An empirical study. Sistemas \& Gesta $o$, $2(1), 1-15$.

Olson, J. R., \& Boyer, K. K. (2005). Internet ticketing in a not-for-profit, service organization: Building customer loyalty. International Journal of Operation \& Production Management, 25(1), 74-92.

Palmer, J. W. (2002). Web site usability, design, and performance metrics. Information Systems Research, 13(2), 151-167.

Parasuraman, A., Zeithaml, V. A., \& Berry, L. L. (1988). SERVQUAL: A multi-item scale for measuring consumer perceptions of service quality. Journal of Retailing, 64(1), 12-40.

Pavlou, P. A. (2003). Consumer acceptance of electronic commerce: Integrating trust and risk with the technology acceptance model. International Journal of Electronic Commerce, 7(3), 101-134.

Pittayachawan, S. (2007). Fostering consumer trust and purchase intention in B2C e-commerce (Doctorate Thesis). Retrieved from http://researchbank.rmit.edu.au

Ponirin, P., Scott, D., \& Von Der Heidt, T. (2009). Does e-store service quality affect customer loyalty? Retrieved from http://papers.ssrn.com/sol3/papers.cfm?abstract_id=1447547

Purosothuman, N. P. (2008). Key determinants of virtual store acceptance among the Malaysians consumers (Master thesis, University of Malaya).

Ramayah, T., Samat, N., \& Lo, M. C. (2011). Market orientation, service quality, and organizational performance in service organizations in Malaysia. Asia-Pacific Journal of Business Administration, 3(1), 8-27.

Rauyruen, P., Miller, K. E., \& Barrett, N. J. (2007). Relationship quality as a predictor of B2B customer loyalty. Journal of Business Research, 60, 21-31.

Ribbink, D., van Riel, A. C., Liljander, V., \& Streukens, S. (2004). Comfort your online customer: Quality, trust, and loyalty on the internet. Managing Service Quality, 14(5), 446-456.

Richins, M. L. (1983). Negative word-of-mouth by dissatisfied consumers: A pilot study. Journal of Marketing, 47, 68-78.

Roca, J. C., García, J. J., \& De La Vega, J. J. (2009). The importance of perceived trust, security and privacy in online trading systems. Information Management and Computer Security, 17(2), 96-113.

Rusman, E., Van Bruggen, J., \& Koper, R. (2007). Theoretical framework for the design and development of a personal identity profile fostering interpersonal trust in virtual project teams. Retrieved from file://C:/Users/Academic/Downloads/00b7d519104fce4616000000.pdf

Salisbury, W. D., Pearson, R. A., Pearson, A. W., \& Miller, D. W. (2001). Perceived security and world wide web purchase intention. Industrial Management and Data Systems, 101(4), 165-176.

Sam, M. F. M., \& Tahir, M. N. H. (2010). Website quality and consumer online purchase intention of air ticket. International Journal of Basic and Applied Sciences, 9(10), 20-25.

Santos, C. P., \& Von Der Heyde Fernandes, D. (2008). Antecedents and consequences of consumer trust on the context of service recovery. Brazilian Administration Review, 5(3), 225-244.

Schoefer, K. (1998). Word-of-mouth: Influences on the choices of recommendation sources (Degree thesis).

Sekaran, U. (1992). Research methods for business: A skill-building approach. New York: John Willey \& Sons.

Serva, M. A., Benamati, J. S., \& Fuller, M. A. (2005). Trustworthiness in B2C e-commerce: An examination of alternative models. Database for Advance in Information Systems, 36(3), 89-108.

Shih, H. P. (2004). An empirical study on user acceptance of e-shopping on the web. Information and Journal, 41, 351-368. 
Shim, J. T., Van Slyke, C., Jiang, J. J., \& Johnson, R. D. (2010). Does trust reduce concern for information privacy in e-commerce. Proceedings from the 7th Annual Conference of the Southern Association for Information Systems.

Smith, E. (2001). Seven steps to building e-loyalty. Medical Marketing and Media, 36(3), 94-102.

Srinivasan, S. S, Anderson, R., \& Ponnavolu, K. (2002b). Customer loyalty: An exploration of its antecedents and consequences. Journal of Retailing, 78, 41-50.

Srinivasan, S. S., Anderson, R., \& Ponnavolu, K. (2002a). Customer loyalty in e-commerce: An exploration of its antecedents and consequences. Journal of Retailing, 78(1), 41-50.

Stanford, J., Tauber, E. R., Fogg, B. J., \& Marable, L. (2002). Experts vs. online consumers: a comparative credibility study of health and finance web r sites. http://www.ebusinessforum.gr/old/content/downloads/comparativeCredibilityStudy.pdf

Suh, B., \& Han, I. (2003). The impact of customer trust and perception of security control on the acceptance of electronic commerce. International Journal of Electronic Commerce, 7(3), 135-161.

Swaminathan, V., Lepkowska-White, E., \& Rao, B. P. (1999). Browsers or buyers in cyberspace? An investigation of factors influencing electronic exchange. Journal of Computer Mediated Communication, 5(2), 1-23.

Tang, T. W., \& Chi, W. H. (2010). The role of trust in customer online shopping behavior: Perspective of technology acceptance model. Retrieved from http://www.casos.cs.cmu.edu

Tarafdar, M., \& Zhang, J. (2008). Determinants of reach and loyalty-A study of website performance and implications for website design. Journal of Computer Information Systems. Retrieved from http://iacis.org/jcis/articles/Tarafdar_Zhang_48_2.pdf

Tax, S. S., Brown, S. W., \& Chandrashekaran, M. (1998). Customer evaluations of service complaint experiences: Implications for relationship marketing. Journal of Marketing, 62, 60-76.

The free encyclopedia. (2011). CyberJaya. Retrieved from http://en.wikipedia.org/wiki/Cyberjaya

Toma, C. (2010). Perceptions of trustworthiness online: The role of visual and textual information. Retrieved from http://research.microsoft.com

Van Der Heijden, H., \& Verhagen, T. (2004). Online store image: Conceptual foundations and empirical measurement. Information and Management, 41, 609-617.

Veloutsou, C., Saren, M., \& Tzokas, N. (2002). Relationship marketing what if? European Journal of Marketing, 36(4), $433-449$.

Wang, Y. D., \& Emurian, H. H. (2005). An overview of online trust: Concepts, elements, and implications. Computers in Human Behavior, 21, 105-125.

Wen, I. (2009). Factor affecting the online travel buying decision: A review. International Journal of Contemporarily Hospitality Management, 21(6), 752-765.

Whitlark, D., Geurts, M., \& Swenson, M. (1993). New product forecasting with a purchase intention survey. Journal of Business Forecasting, 12(3), 10-13.

Wolfinbarger, M., \& Gilly, M. C. (2003). E-tail-Q: Dimensionalizing, measuring, and predicting e-tail quality. Journal of Retailing, 79(3), 193-198.

Yang, Z., Jun, M., \& Peterson, R. T. (2004). Measuring customer perceived online service quality: Scale development and managerial implications. International Journal of Operations \& Production Management, 24(11), 1149-1174.

Yao, W, K., Zhou, M. H., \& Meng, J. (2007). Value-based customer loyalty evolution. Service Operations and Logistics, and Informatics. Retrieved from http://ieeexplore.ieee.org

Ye, N., \& Jia, J. (2010). Customer's perceived service quality of internet retailing. Retrieved from http://ieeexplore.ieee.org

Zawawi, S. N. H. M., Yusuf, S. N. S., \& Khan, N. I. (2004). A study on the awareness of e-commerce amongst the bachelor of accountancy students in public universities in Klang Valley. Journal of Financial Reporting and Accounting, 2(1), 31-42.

Zeithaml, V. A., Parasuraman, A., \& Malhotra, A. (2002). Service quality delivery through web sites: A critical review of extant knowledge. Journal of the Academic of Marketing Science, 30(4), 358-371. 